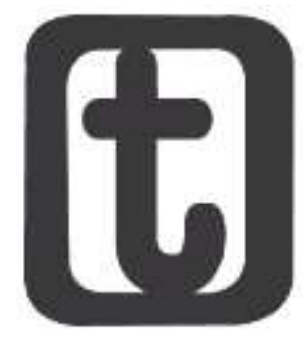

\title{
LUTA ANTIRRACISTA, TRADIÇÃO MARXISTA E O MAIO DE 68
}

\author{
The antiracist struggle, Marxist tradition and May of 68 \\ Sandra Regina Vaz Silva* \\ https://orcid.org/0000-0002-2218-7318
}

\section{RESUMO}

Buscando discorrer sobre a luta antirracista em diálogo com a tradição marxista, pretendemos nesse artigo apontar a influência, os limites e tensionamentos implícitos nessa relação, utilizando o Maio de 68 como referência desse estudo. Nossa proposta é refletir sobre a luta antirracista no período anterior e posterior a esse marco, pois comumente essa luta é definida como pós-moderna e fragmentadora da luta de classes, uma forma equivocada e a-histórica de conceber seu significado e definição. Se por um lado, é possível identificar setores identitários e pós - modernos no interior do movimento negro, há também um caminho e descaminho produzido pela tradição marxista que é parte dessa história e que necessita de um balanço histórico, de modo a enfrentar os erros e acertos dessa relação.

\section{PALAVRAS - CHAVE}

Luta Antirracista, Luta de Classes, Tradição Marxista.

\section{ABSTRACT}

Seeking to discuss the anti-racist struggle in dialogue with the Marxist tradition, we intend in this article to point out the influence, limits and tensions implicit in this relationship, using the May 68 as a reference of this study. Our proposal is to reflect on the anti-racist struggle in the period before and after this milestone, as it is commonly defined as postmodern and fragmentary of class struggle, a mistaken and ahistorical way of conceiving its meaning and definition. If, on the one hand, it is possible to identify identity and postmodern sectors within the black movement, there is also a path and misalignment produced by the Marxist tradition that demarcates this history and that needs to be recovered in order to address the errors and successes in this relationship.

\section{KEYWORDS}

Anti-Racist Fight, Class Fight, Postmodernity.

Submetido em: 7/10/2019.

Aceito em: 28/4/2020.

\footnotetext{
* Assistente Social. Doutoranda do Programa de Pós Graduação em Serviço Social da UFRJ. Professora da Escola de Serviço Social da Universidade Federal Fluminense. (UFF, Niterói, Brasil). R. Alexandre Moura, 8 São Domingos, Niterói (RJ), CEP.: 24210-200. E-mail: sandravaz@id.uff.br.
}

DOI 10.22422/temporalis.2020v2on39p146-162

(cc) BY $\mathrm{EY}$ A(s) Autora(s)/O(s) Autor(es). 2019 Acesso Aberto Esta obra está licenciada sob os termos da Licença Creative Commons Atribuição 4.0 Internacional (https://creativecommons.org/licenses/by/4.o/deed.pt_BR), que permite copiar e redistribuir o material em qualquer suporte ou formato, bem como adaptar, transformar e criar a partir deste material para qualquer fim, mesmo que comercial. O licenciante não pode revogar estes direitos desde que você respeite os termos da licença.

Temporalis, Brasília (DF), ano 20, n. 39, p. xx-xx, jan./jun. 2020. | ISSN 2238-1856 


\section{INTRODUÇÃO}

$\mathrm{O}$

artigo tem como objetivo discorrer sobre a luta antirracista em diálogo com a tradição marxista, de modo a apontar a influência, os limites e tensionamentos implícitos nessa relação.

Como ponto de partida de nossas reflexões, destacamos o Maio de 68 como marco histórico e político, desencadeador da chamada nova esquerda e dos novos movimentos sociais, comumente relacionados à luta antirracista. Identitarismo, pós-modernidade e fragmentação da luta de classes são elementos que compõem tais análises e fundamentam nossas indagações, pois, embora o Maio de 68 tenha ocasionado um giro teórico-político nas lutas sociais, a influência de Marx e da tradição marxista na luta antirracista é anterior a esse marco histórico.

Nesse sentido, procuraremos apontar o diálogo e a influência da tradição marxista na luta antirracista, os equívocos e tensionamentos dessa relação, de modo a evidenciar que ela antecede a chamada crise de paradigmas instaurada na academia nos anos 60 , mas que este marco fortalece uma vertente das lutas sociais distante das tradicionais formas de organização da luta de classes, que necessitam ser compreendidos mediante as mudanças do capitalismo, a crise do marxismo e do socialismo real. Essas mudanças desencadearam também o fortalecimento de outras tendências dentro da própria esquerda marxista.

Aliado a esse processo histórico, compreender a luta antirracista antes e depois do Maio de 68 , sobretudo no Brasil, nos coloca o grande desafio de identificar a tênue relação da esquerda, em meio a diversidade que é o movimento negro e a incorporação da pauta racial de forma mais incisiva nos documentos e programas das organizações partidárias, ao final dos anos 70.

Consideramos o desvelar da proposta de fundamental importância para um balanço histórico dos limites e possibilidades de avanço da luta antirracista nas organizações de esquerda no Brasil, seu reconhecimento e efetiva incidência, concebendo-a como componente intrínseco à luta de classes.

\section{O MAIO DE 68 E A LUTA ANTIRRACISTA}

O Maio de 68 ficou conhecido como um marco na história mundial, devido a eclosão de um conjunto de manifestações políticas protagonizadas inicialmente por estudantes através de ocupações, atos, assembleias e outras formas de protestos que reivindicavam melhorias no setor educacional.

Tendo como berço de seu surgimento uma universidade da região de Paris, na França, esses protestos marcaram um período de efervescência das lutas sociais que extrapolou o âmbito educacional e alcançou manifestações como as greves operárias, que reuniram cerca dez milhões de trabalhadores e paralisaram fábricas, transportes e serviços públicos, as denúncias contra a guerra do Vietnã, o fim do capitalismo e outras reivindicações. Apesar de considerada como idealista, essas manifestações sofreram duras repressões e impulsionaram a expansão das lutas sociais pelo mundo. 
O Maio de 68 deve ser compreendido como o marco divisor das lutas sociais, resultado das mudanças estruturais ao longo da década de 60. Isso porquê, foi à partir daí que houve o surgimento (ou visibilidade) da chamada nova esquerda e novos movimentos sociais, ou seja, um conjunto de lutas sociais que passaram a ganhar ascensão no período e se diferenciar do marxismo tradicional no campo teórico e político.

O Maio de 68 teve a academia como terreno fértil. Nascia nesse espaço uma nova interpretação da realidade - a teoria pós-moderna - que atribuindo aos novos sujeitos sociais o confronto com os velhos sujeitos revolucionários, alcançava no seio de uma nova esquerda vários tensionamentos e contradições. A crise da razão moderna seria o fundamento desta mudança, pois em grande medida, há a compreensão de que "[...] a realidade é um todo fragmentado, marcado pela efemeridade, pela fragmentação e pela indeterminação, o que impossibilita existir uma narrativa ou metanarrativa capaz de explicar a totalidade da vida social" (DURIGUETTO, 2009, p. 4).

Apesar da característica pragmática e imediatista, como é considerada por críticos à essa tendência teórica, esse debate deve ser compreendido como produto da complexidade em que o ser social se instituiu no mundo capitalista, e por isso, não podemos apontá-lo como significante em si mesmo (EVANGELISTA, 2002).

É preciso considerar ainda que a crise do marxismo e/ou do socialismo real e a crise do capitalismo durante os longos anos 60 foi primordial para a emergência dos novos movimentos sociais, a exemplo do movimento estudantil, feminista, homossexual, negro, ecológico e pacifista, ao passo do esmorecimento das lutas operárias dirigidas pelos sindicatos e partidos de base tradicional.

Embora os longos anos 60 tenha sido o marco de tais mudanças, podemos considerar que as transformações no âmbito acadêmico-científico e tecnológico se originou na década anterior, ou seja, nos anos 50, e desencadeou a chamada crise de paradigmas, que, adentrando o campo ídeo-cultural através de produções artísticas e científicas, extrapolou continentes e influenciou a realidade brasileira em fins do século $X X$, em meio à efervescência das lutas sociais por aqui protagonizadas.

Os determinantes econômicos e políticos são fundamentais para a compreensão de tais mudanças teórico-políticas. De acordo com Hobsbawm (1995), a Era de Ouro ou os trinta anos gloriosos significou uma fase excepcional da história do capitalismo monopolista nos países industriais, que alcançou cerca de três quartos da produção mundial e $80 \%$ das exportações manufaturadas.

Após a Segunda Guerra Mundial, os Estados Unidos passou a dominar a economia do mundo, sobretudo com a continuidade e expansão dos anos da guerra, apesar do seu baixo desempenho durante os Anos Dourados, se comparado a outros países industriais.

Por outro lado, a ameaça da Guerra Fria e a ascensão dos partidos comunistas teria sido o combustível para o avanço da economia capitalista mundial, sob financiamento de uma política americana que fez emergir o desenvolvimento em torno de si. O domínio interno e superestrutural dos Estados Unidos em sua dimensão militar e econômica inaugurada sobre o resto do mundo, trouxe como consequência de sua hegemonia "[...] sangue, tortura, morte e terror" (JAMESON, 1996, p. 31). 
Ao longo dos anos de 1960, uma economia mundial e sem fronteiras definidas, ganhou cada vez mais força e extensão, até alçar crise. O compromisso fordista, como apontado por Bihr (2010), foi o combustível necessário para o crescimento, via transnacionalização, divisão internacional do trabalho e financiamento externo. Nesse processo histórico, o crescimento em escala e as exportações dos países considerados de Terceiro Mundo para os países industriais adquiriram força.

Contudo, as consequências desse processo não sobreviveram à crise do final dos anos 60 . Os desgastes sinalizaram o declínio da hegemonia dos EUA e de seu sistema monetário, assim como a diminuição da produtividade da mão de obra de diversos países.

Crescia uma nova geração em meio ao desemprego, insegurança e instabilidade de preços, que, tendo convivido com a fase de ouro do capitalismo, tal qual, o pleno emprego e a inflação contínua, despertou para uma realidade atípica da Era de Ouro, embora inevitável ao capitalismo. Como destaca Hobsbawm (1995):

\begin{abstract}
Qualquer que tenha sido a situação responsável pela 'explosão mundial de salários' no fim da década de 1960 - escassez de mão de obra, crescentes esforços dos patrões para conter os salários reais, ou, como na França e na Itália, as grandes rebeliões estudantis - tudo se assentava na descoberta, feita por uma geração de trabalhadores acostumados a ter ou conseguir emprego, de que os reguladores e bem - vindos aumentos há tanto negociados por seus sindicatos eram na verdade muito menos do que se podia arrancar do mercado. Detectemos ou não um retorno à luta de classes nesse reconhecimento de realidades do mercado (como afirmaram muitos na 'nova esquerda' pós 68), não há dúvida sobre a impressionante mudança de estado de espírito entre a moderação e a calma das negociações salariais antes de 1968 e os últimos anos da Era de Ouro (HOBSBAWM, 1995, p. 280).
\end{abstract}

O fim da Era de Ouro mostrou que o consenso não sobreviveu aos longos anos 60 e trouxe consigo o colapso do sistema financeiro internacional, crises e debilidades da expansão econômica. O pleno emprego, a proteção social e a aquisição de bens de consumo estavam com seus dias contados. Nas palavras de Mandel (1982) "[...] a contradição entre socialização crescente do trabalho e apropriação privada [...]” (MANDEL, 1982, p. 138-139) já não estavam em consonância.

Assim, uma ruptura entre o proletariado ocidental e as organizações sindicais e políticas da social democracia resultaram em um novo momento das lutas e reivindicações, ancoradas na igualdade dos indivíduos, solidariedade social e incorporação de valores oriundos dos novos movimentos sociais, que emergiram no seio das lutas proletárias (BIHR, 2010).

Uma crise estrutural global, decorrente do capital e suas contradições, colocaram em xeque o movimento operário e seu modelo social - democrata, e com isso a fragmentação do proletariado, culminando em uma crise ecológica, de sociabilidade e cultural (BIHR, 2010).

A generalização sociológica, baseada sobretudo no pós - estruturalismo, passou a denominar a sociedade como pós-industrial, sociedade do consumo, das mídias, da informação e assim por diante, e o que tais concepções representaram de fato foi o

Temporalis, Brasília (DF), ano 20, n. 39, p. 146-162, jan./jun. 2020. | ISSN 2238-1856 
rompimento com o capitalismo clássico e a primazia da produção industrial e da luta de classes (JAMESON, 1996).

Sobre a luta antirracista, comumente setores da esquerda a identificam como uma questão identitária e/ou pós-moderna, fragmentadora da luta de classes. Consideramos que tais afirmações partem significativamente de concepções que concebem a influência do Maio de 68 - e a eclosão dos novos movimentos sociais ${ }^{1}$ - sem as devidas mediações necessárias sobre a luta antirracista, a tradição marxista e a realidade brasileira.

Pretendemos então, historicizar a luta antirracista de modo a evidenciar seu diálogo com a tradição marxista, muito antes do Maio de 68. Afirmamos que essa análise deve estar fundamentada nos determinantes econômicos e políticos que marcaram o século XX, como o cenário de crise do marxismo (ou do socialismo real) e a crise mundial do capital.

Sobre a importância e influência do pensamento de Marx, destacamos que uma tradição teórico - crítica foi sendo erguida em fins do século XIX e início do século XX. Ao mesmo tempo, uma tradição teórico-socialista e comunista foi ganhando notoriedade através de análises fecundas, originais, inovadoras e, como queremos destacar, algumas vezes distante das ideias de Marx (BRAZ, 2011).

A questão racial à luz da tradição marxista trouxe significativas contribuições e legados à luta da população negra na diáspora, apesar das polêmicas, tensões e equívocos em torno dessa relação. A experiência da Revolução Russa influenciou o movimento negro nos Estados Unidos, América Latina e África, fazendo avançar em uma luta contra as potências capitalistas do período. Essas lutas tiveram reivindicações de caráter socialista, anticapitalista, de libertação nacional e ganhou força no início do século XX.

Vale destacar a formação de importantes líderes históricos articulados a experiência soviética, mas que no decorrer dos anos foram rompendo com o comunismo e construindo a luta antirracista sob diferentes formas de organização. Alguns deles romperam com o marxismo e outros, mesmo cindindo com o comunismo, continuaram a utilizar o método em Marx como análise e inspiração revolucionária no combate ao racismo, o capitalismo e o colonialismo².

Apesar das diferentes tendências na interpretação marxista, podemos destacar que o movimento de libertação nacional nos países africanos esteve influenciado por essa tradição, através de importantes líderes como Agostinho Neto, Kwame Nkrumah, Samora Machel, Stive Biko, Frantz Fanon e outros mais. As lutas protagonizadas por mulheres negras estadunidense também deixaram um importante legado a luta antirracista, com destaque para a luta pelos direitos civis nos Estados Unidos e lideranças como Ângela

\footnotetext{
${ }^{1}$ Conforme destaca Duriguetto (2009): “[...] com a erosão da identidade de classe, enquanto identidade unificadora e abrangente, as identidades foram se fragmentando e se reestruturando a partir de novos e múltiplos referenciais e interesses, sempre parciais, e não mais universais e abrangentes como antes. Ou seja, interesses universais e de classe são substituídos por objetivos grupais específicos e localistas dos novos movimentos sociais" (DURIGUETTO, 2009, p. 5).

${ }^{2}$ A esse respeito, sugerimos conhecer a história do Pan-Africanismo em suas diferentes tendências teóricopolíticas e gerações, pois uma delas dialoga com o legado marxista, como demonstra a produção de Barbosa (2011/2012).
}

Temporalis, Brasília (DF), ano 20, n. 39, p. 146-162, jan./jun. 2020. | ISSN 2238-1856 


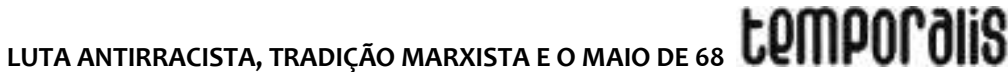

Davis, Assata Shakur e o próprio Partido dos Panteras Negras que tinha inspiração marxista leninista - maoísta.

A questão racial ganhou atenção junto a tradição marxista através de Lênin. Esse marco ocorreu no $1^{\circ}$ Congresso da Internacional Comunista em 1919, através da tese que mencionava a falsa "[...] promessa de igualdade racial, religiosa e sexual das democracias burguesas" (CHADAREVIAN, 2007, p. 83). Já em 1920, Lênin destacou a situação das colônias e dos negros dos Estados Unidos, como também dos judeus, irlandeses e alsacianos, apontando como problemas nacionais e portadores do direito de organizar sua própria nação. Essa compreensão pretendia defender a autonomia política das nações, ou a autodeterminação dos povos, de acordo com as relações de opressão estabelecidas pelos países mais desenvolvidos.

Mas foi em 1922 que houve efetivamente a inserção do debate racial, através da incorporação da Tese sobre a "Questão Negra", nas resoluções do IV Congresso da III Internacional Comunista. Até então, esse reconhecimento resumia-se à ideia de que a população negra e branca eram reféns do sistema capitalista (CHADAREVIAN, 2007).

Apesar disso, a morte de Lênin desencadeou tensões e polêmicas sob a temática, e, concomitantemente, o movimento comunista internacional foi adquirindo resistência e fazendo com que o debate teórico-político sobre a questão racial alcançasse conflitos e crises, mesmo mantido nas diretrizes do partido comunista, como Chadarevian (2007) destaca:

\begin{abstract}
Esta resistência em aplicar as determinações teóricas e políticas de Moscou gerou, de um lado, uma crise que terminaria com a expulsão de diversos líderes dos partidos comunistas dos países em questão; de outro lado, provocou um atraso na avaliação teórica e na atuação política sobre a questão racial nesses países. 0 problema se manifestava especialmente naquelas regiões em que o domínio colonial já se havia consolidado desde algum tempo. Estes eram os casos da Indonésia, definitivamente subordinada ao império colonial holandês em 1830; da Argélia, colônia francesa a partir de 1833; da Índia, possessão britânica desde 1849; e dos territórios portugueses na África. De uma forma geral, a posição oficial dos PC nestes países era, no mínimo, contraditória. Contraditória com preceitos teóricos do marxismo, mas, sobretudo, com os princípios de integração à III Internacional Comunista. Evitava-se, nestes partidos, atacar o colonialismo, chegando mesmo a justificá-lo com o argumento de 'missão civilizatória', incluindo nesta missão o socialismo - ou seja, a independência das colônias só poderia vingar desde que liderada pelo comunismo das metrópoles (CHADAREVIAN, 2007, p. 89-90).
\end{abstract}

Tensionamentos foram sentidos nas mudanças e posicionamentos sobre o colonialismo e o imperialismo em África e nas comunidades negras da diáspora. Conforme aponta Nascimento (1981), havia por trás um interesse meramente tático e partidário, ao contrário do compromisso com a luta antirracista.

Houveram situações que foram desencadeando vários descontentamentos por parte da militância negra, como o desmantelamento da Liga Contra o Imperialismo em 1934-1935, a inserção da União Soviética na Liga das Nações e as alianças estabelecidas, o fechamento do Comitê Internacional de Sindicatos de Trabalhadores Negros. Além disso, o estopim foi 
gerado devido à posições racistas nas fileiras da Internacional Comunista e seu apoio à invasão da Etiópia, o que provocou afastamentos da militância negra e também indignações, sobretudo com a retomada da campanha anti-colionialista e anti-imperialista, pela defesa propagandista das massas oprimidas da África e Ásia, e o pacto de não agressão entre Hitler e Stálin em 1939. A disputa considerada como oportunista por parte do PC pela direção do Congresso Nacional do Negro nos EUA, a Guerra do Vietnã e as acusações equivocadas aos soldados negros foram outros elementos que revelaram o desgaste nessa relação.

Sobre a Guerra do Vietnã, Nascimento (1981) ressalta que as posições, especialmente de "[...] exilados políticos latinos, demonstraram uma indiferença total dos efeitos do racismo sobre a comunidade negra no contexto da convocação militar, e uma insensibilidade extrema à realidade do racismo nas forças armadas" (NASCIMENTO, 1981, p. 65).

Vale destacar que um importante elemento que tange os preceitos teóricos do marxismo, refere-se a interpretação da realidade sob um teor economicista e mecanicista do período stalinista. Os efeitos dessa análise impactou o mundo, e em especial o próprio marxismo, pois resultou em muitos erros e equívocos de modo geral.

De acordo com Lowy (2012), uma interpretação marxista esquemática e etapista marcou a América Latina entre 1930 e 1959, e após esse período, as revoluções inspiradas em outras correntes do marxismo, à grosso modo, o castrismo, o guevarismo, o trotskismo e o maoísmo adquiriram forças. Notavelmente também se destaca em solos latino - americano a teologia da libertação, difundida pelo movimento de cristãos nos diferentes espaços populares. É fato que a crise dos partidos comunistas após 1959, suas divergências e dissidências foram terreno fértil para a elevação dessas tendências, inclusive para o desencadeamento da chamada crise de paradigmas que tempos depois se instalaria na academia.

Tomando como referência o marxismo no século XX, Hobsbawm (1989) aponta três importantes acontecimentos para a compreensão do marxismo na contemporaneidade:

[...] aqueles ligados aos desdobramentos na URSS e nos outros países socialistas a partir de 1956; aqueles ligados ao que já nos anos 50 se começou a chamar (com um termo equívoco) 'terceiro mundo', particularmente a América Latina; e, por fim, aqueles ligados à impressionante e inesperada explosão de radicalismo político nos países do capitalismo industrial ao final dos anos 60 , cujas premissas principais devem ser buscadas nos movimentos estudantis. Decerto, não nos propomos confrontar esses diferentes acontecimentos, a não ser pela relação que possam ter tido com a discussão marxista. Quanto a seu significado político efetivo, direto ou indireto, eles são de valor muito diferente, mas não podem ser nitidamente separados, especialmente a partir de 1960 (HOBSBAWM, 1989, p. 19).

Para o autor, o processo de destalinização gerou desdobramentos tanto na URSS como também nos demais países socialistas após 1956. Os efeitos teórico-práticos desse processo, gerou uma onda de reformulações e revisões diante da nova situação internacional que se acirrava entre URSS, China, os demais Estados socialistas e sua relação com o mundo capitalista, com o terceiro mundo e com o próprio movimento comunista internacional. 


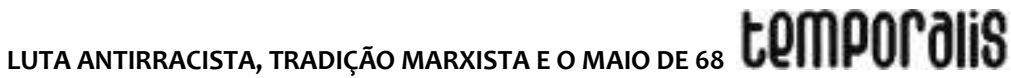

Todo esse contexto de crise redundou em novas interpretações do marxismo (e muitas vezes distante dele), cujo ascenso de uma nova esquerda intelectual, que surgia em meio a radicalidade do movimento estudantil dos anos 60 na Europa, foi a consequência máxima. E como analisa Hobsbawm (1989), não havia relação com a insatisfação econômica e de crise, pois essa emergência ocorreu no seio dos milagres econômicos e expansão capitalista que favorecia os estudos e carreiras estudantis. Sua diretriz teve caráter social e cultural, como nos mostra:

\begin{abstract}
Se havia uma disciplina que representasse essa busca de uma crítica da sociedade em seu todo, era a sociologia, e esta, de fato, atraiu os estudantes radicais em número desproporcional, a ponto de ser identificada muitas vezes com o radicalismo da 'nova esquerda'. Em segundo lugar, não obstante a ligação tradicional do marxismo com a classe operária (e, em sua versão terceiromundista, com os camponeses), os jovens intelectuais radicalizados eram, em virtude de seu nível de vida e de suas origens sociais, distintos, seja dos operários, seja dos camponeses, por mais que em teoria se identificassem apaixonadamente com eles. Se eram filhos da burguesia constituída, podiam no máximo 'ir até o povo', tal como populistas de última hora, ou gabarem-se dos relativamente poucos proletários, camponeses ou negros que se uniam efetivamente a seus grupos. Se eram, eles mesmos, de extração proletária, camponesa ou, mais comumente, pequeno-burguesa, sua situação e suas expectativas profissionais os levavam automaticamente para fora do contexto social de origem. Não eram mais operários ou camponeses, ou não eram mais vistos como tais por seus pais, parentes e amigos. Além disso, suas idéias políticas tendiam a ser muito mais radicais que as da grande maioria dos operários, ainda quando (como no maio francês de 1968) se viram juntos na ação militante (HOBSBAWM, 1989, p. 43).
\end{abstract}

Apesar de expressarem uma luta considerada isolada e muitas vezes distante dos interesses da classe operária, o processo de reformulação e revisão permitiu alcançar um certo pluralismo frente a ortodoxia obrigatória que até então existia. Esse feito não ocultou os conflitos, e, ao contrário, explicitou as diferentes tendências teórico-políticas e a multiplicidade de agrupamentos e organizações, sobretudo à esquerda dos antigos partidos comunistas, que trouxe consigo diferentes combinações ideológicas como a perspectiva católica, islâmica e nacionalista, ou até mesmo um apelo a Marx ou qualquer outro marxista que sustentasse a ideologia em disputa (HOBSBAWM, 1989).

Assim, é preciso considerar que o Maio de 68 desencadeou diferentes projetos de inspiração de esquerda, tendências anarquistas e libertárias, o fortalecimento do marxismo - maoísmo e dissidências culturais apolíticas e até mesmo antipolíticas.

Diante desse raciocínio, o que pretendemos demonstrar até aqui é que as lutas sociais que se destacaram à partir do Maio de 68 , denominadas como lutas identitárias e/ou pós modernas, ou de influência pós - estruturalistas, apesar de sua radicalidade, desencadeou também em um antimarxismo e uma rechaça à todo e qualquer movimento de esquerda de base classista, que deve ser analisado juntamente com o fortalecimento/eclosão das diferentes tendências da própria esquerda marxista de base classista no período. Aliado a isso é preciso considerar as particularidades de cada país influenciado por tais tendências.

No Brasil, frequentemente e hegemonicamente a luta antirracista é meramente reduzida as perspectivas citadas acima. Ao mesmo tempo, existem setores do movimento negro que negam a influência de Marx e da tradição marxista na luta antirracista, com a afirmação

Temporalis, Brasília (DF), ano 20, n. 39, p. 146-162, jan./jun. 2020. | ISSN 2238-1856 
de haver historicamente um processo de negligência, secundarização da pauta e o não reconhecimento da importância da luta antirracista para a luta de classes. Indo além, denunciam a presença do racismo nas fileiras de algumas organizações de esquerda. Por outro lado, vale ressaltar a falta de conhecimento (ou de reconhecimento) da influência de Marx e da tradição marxista na luta antirracista, no próprio interior das organizações de esquerda.

Como aproximação à essas indagações, é preciso esclarecer que, a luta do movimento negro extrapola a forma mais clássica, relacionada às demandas da classe operária, pois, se é a população negra a base dessa classe, ocupando os espaços mais subalternos e precarizados, é a população negra também àquela parcela que mais sofre com o desemprego. E o racismo é o determinante dessa realidade.

Assim, o movimento negro deve ser apreendido enquanto movimento social que detém complexidade e multiplicidade na sua forma de organização (PEREIRA, 2013), e por ser tão diverso, abarca diferentes perspectivas teórico-políticas como qualquer outro movimento social aglutinador das massas. O movimento negro tem como centralidade de sua luta o combate ao racismo, por compreender a categoria raça como uma construção sóciohistorica, que, embora inexistente em seu sentido biológico, socialmente, ideologicamente e economicamente estruturou a formação da sociedade e se mantém de forma dinamizadora 3 .

O movimento negro conta em sua construção, com a participação de coletivos autônomos, militantes de organizações partidárias e sindicais, grupos religiosos, setores culturais e educacionais. Há, portanto, no movimento negro, setores classistas e outros que defendem os mais distintos projetos societários e partem de diferentes tendências teóricopolíticas.

Consideramos então, que há uma junção de tendências e perspectivas dentro dessa relação do movimento negro em sua multiplicidade, que se aproxima dos velhos e dos novos movimentos sociais. Em síntese, se diferenciam entre uma abordagem mais culturalista e outra de caráter classista.

Diante dessa diversidade, considerar a luta antirracista como movimento meramente identitário, é de fato desconhecer a história e o protagonismo de importantes líderes negros anticapitalistas, anti-imperialistas e anti-coloniais, suas respectivas lutas e formas de mobilizações que puseram em xeque as estruturas das sociedades no século XX. É também desconsiderar a luta antirracista dos setores vinculados à esquerda em suas diferentes tendências e formas de organização, que vêm apontando a necessidade de incorporação de ações efetivas de combate ao Racismo em articulação com a luta de classes. Por fim, é não reconhecer os equívocos históricos na relação entre luta antirracista, tradição marxista e luta de classes.

\footnotetext{
${ }^{3}$ De acordo com Almeida (2018), é preciso compreender o racismo como processo histórico e político, e a forma como se constituem as relações políticas, econômicas e jurídicas na sociedade, que fazem com que "[...] direta ou indiretamente, grupos racialmente identificados sejam discriminados de forma sistemática" (ALMEIDA, 2018, p. 34).
} 


\section{A LUTA ANTIRRACISTA NO BRASIL}

No Brasil, o racismo foi sendo estruturado por um sistema econômico, político e social desigual, que mantido até a atualidade, apresenta efeito dinamizador e mantenedor de tais relações. Conforme Moura (1988) assinala, a divisão social e racial do trabalho determinou o grau de exploração, acumulação e manutenção de um sistema erguido sob e para uma elite branca, e a manutenção de seus privilégios.

No que se refere a luta antirracista na esquerda, o Partido Comunista Brasileiro, apesar de fundado em 1922, reconheceu a questão racial em seus documentos somente na década seguinte. Até a década de 30 havia um pensamento hegemônico que acreditava não haver racismo no Brasil, apesar do Estado brasileiro em seu projeto de desenvolvimento nacional, utilizar-se de medidas que buscavam branquear a população brasileira e ao mesmo tempo criminalizar a população negra e sua cultura.

Desde 1928 a Internacional Comunista adotava a política do direito de autodeterminação dos povos indígenas e negros. Essa orientação foi a base para o PCB incidir gradualmente na luta, apesar dos passos lentos.

Partindo de uma visão etapista da evolução do capitalismo, Chadarevian (2012) afirma que a interpretação teórica do partido sobre a realidade econômica nacional acabou por fragilizar a análise do problema racial, conforme descreve:

\footnotetext{
Procuraremos mostrar que a crítica deficiente ao problema racial por parte do PCB está relacionada à interpretação teórica do partido para a realidade econômica nacional em um país considerado semicolonial, independente politicamente, mas subordinado ao capital estadunidense e, no plano interno, a uma classe dominante agrária feudalista. Como resultado, a economia do país se via presa a estruturas arcaicas, que impediam o pleno desenvolvimento das forças produtivas capitalistas. Na visão etapista da evolução do capitalismo própria ao marxismo-leninismo, isto significava que o Brasil ainda não havia realizado, à época, uma 'revolução burguesa', com a consequente modernização das relações salariais, da estrutura fundiária e do parque industrial. É no âmbito desta leitura particular da economia brasileira que deve ser compreendida a interpretação da questão racial pelo PCB entre 1922 e 1964. O racismo era visto, assim, como um elemento adicional que caracterizava a estrutura semifeudal prevalecente no país, na medida em que os trabalhadores negros e os indígenas estariam submetidos a um regime de trabalho arcaico, 'escravista', sem direito à terra nem à organização política (CHADAREVIAN, 2012, p. 258).
}

A mudança do posicionamento do PCB decorreu de alguns fatores centrais, como a orientação da Internacional Comunista, o surgimento do movimento negro urbano organizado, a ausência de debates fundados no racismo científico no Brasil ao passo da influência do pensamento de Gilberto Freyre no pensamento social brasileiro à época.

Após 1934, ocorre o que pode ser considerado a primeira análise marxista da questão racial, feita por Edson Carneiro, no $1^{\circ}$ Congresso Afro-brasileiro.

Carneiro, destacado antropólogo e militante comunista, apresenta na ocasião aquela que pode ser considerada a primeira análise marxista da questão negra no Brasil. Sua intervenção no Congresso começa com uma crítica do processo de

Temporalis, Brasília (DF), ano 20, n. 39, p. 146-162, jan.jun. 2020. | ISSN 2238-1856 
abolição da escravatura, relacionada, segundo ele, à necessidade do trabalho assalariado, que produz mais-valia absoluta, e onde a exploração do trabalhador pode ser levada ao extremo [...] (CARNEIRO, 1988 [1935], p. 237). No novo regime, salarial, os negros continuam sendo escravos, agora do capitalismo, e sofrem a 'opressão racial dos homens brancos'. Os fatores desta opressão têm uma origem tanto interna quanto externa. O raciocínio acima demonstra que o autor estava bem informado sobre a política comunista para a questão negra, e chega mesmo a afirmar que a luta do negro é ao lado do operariado, e, mais especificamente, no $\mathrm{PCB}$, que vinha, segundo ele, recebendo grandes contingentes de negros à época. No final da intervenção, o autor aponta o papel progressista dos comunistas para a questão negra, mencionando sua defesa ao direito de autodeterminação, e conclui afirmando que o socialismo é a melhor solução para ultrapassar o racismo (CHADAREVIAN, 2012, p. 265-266).

Buonicore (2005) também nos mostra que houveram algumas aproximações da intelectualidade comunista à questão racial no período, à exemplo de Leôncio Basbaum que, como afirma o autor, foi o intelectual que mais se dedicou ao problema racial no Brasil. Embora seu pensamento não tenha representado oficialmente o posicionamento de seu partido, o autor assinala:

O seu livro pioneiro A Caminho da Revolução, publicado em 1934 com o pseudônimo Augusto Machado, possui um capítulo intitulado 'A questão das raças e nacionalidades', que começa assim: 'No Brasil não há apenas o choque das classes - há também o das raças e das nacionalidades, ainda que este em muito menor importância que aquele'. Por isso seria 'impossível tratar da Revolução operária e camponesa no país sem pensar nesses problemas' e seria 'um grande erro pensar que são problemas de após a revolução. Essa falsa opinião ainda vigorante mesmo em alguns membros dirigentes do $P C B$, convém ser vigorosamente combatida'. Lembremos que quando Basbaum escreveu este livro estava afastado, e às turras com, da direção do PCB. Assim sendo, o texto não refletia as posições oficiais deste partido - embora estivesse em sintonia com as teses da Internacional Comunista (BUONICORE, 2005, p. 11).

Apesar dos equívocos na análise, é importante destacar que as ideias marxistas que emergiram no Brasil entre o século XIX e início do século XX, tinham uma base eclética e misturadas a outras teorias estranhas à Marx. Nesse sentido, consideramos relevante destacar o processo de interpretação do marxismo na realidade brasileira, pois acreditamos ter influência direta sobre a questão racial.

De acordo com Konder (1984), haviam muitas dificuldades em conhecer o pensamento de Marx, e em escala maior que na Europa, devido ao acesso direto de seus escritos e compreensão. Somente em 1922, com a fundação do PCB, foi possível criar um centro nacional de difusão do marxismo.

Com isso, à partir dos anos 30 o marxismo passou a ser mais difundido, alcançando adeptos e propagandistas. Contudo, não houve aprofundamento sobre o pensamento de Marx e sim uma mistura e subordinação a Lênin e Stálin. Ou seja, "[...] a discussão sobre as ideias de Marx tinha ficado atrelada, de forma empobrecedora, à discussão sobre a evolução da experiência soviética, sobre a importância universal do Estado soviético" (KONDER, 1984, p. 34).

Em 1935, a perseguição e repressão aos comunistas brasileiros e seus aliados culminou na radicalização da ofensiva antimarxista pelo Estado Novo. Por outro lado, o PCB viveria nos

Temporalis, Brasília (DF), ano 20, n. 39, p. 146-162, jan./jun. 2020. | ISSN 2238-1856 
anos seguintes, uma série de mutações e inflexões nos seus posicionamentos teóricopolíticos, até chegar às portas do golpe de 1964.

Sobre o movimento negro, Pereira (2013) aponta três importantes marcos da luta do movimento negro na história do século XX. O primeiro se destaca pela fundação da Frente Negra Brasileira aliado à imprensa negra, grêmios, clubes e associações negras. O segundo se refere a criação do Teatro Experimental do Negro (TEN), de Abdias Nascimento na década de 40, e por fim, o terceiro marco seria a reorganização do movimento negro numa perspectiva de transformação social e anticapitalista, no final da década de 1970. Em toda história, a luta contra o racismo, as denúncias contra a desigualdade racial e contra o mito da democracia racial foram elementos centrais.

Foi nos anos 50 que houve uma elevação da produção de estudos e pesquisas da realidade brasileira que somaram força e denúncia contra a ideia da existência de uma democracia racial no país, pensamento oficial da época.

No aspecto político-econômico, a hegemonia imperialista estadunidense, ao se articular cada vez mais à autocracia burguesa brasileira no processo desenvolvimentista, só fez aprofundar o caráter dependente do capitalismo brasileiro, enquanto a era fordista/keynesiana caminhava para o seu declínio, nos países europeus de economia capitalista desenvolvida.

Mas, como Netto (2011) irá mostrar, o regime autocrático burguês provocou significativos processos de oposição e resistência no Brasil. Com o agravante retrocesso e aprofundamento da crise no plano político-econômico e da vida social e cultural, novas reflexões críticas foram emergindo após os anos 80 e inaugurando no plano educacional, "[...] um novo pensamento social de oposição, explicitamente reclamando-se de esquerda" (NETTO, 2011 p. 103).

Contudo, Netto (2011) afirma que essa inspiração de esquerda em sua diversidade expressou também um novo irracionalismo, vinculado a perspectiva revolucionária, que formou um antielitismo, antiautoritarismo e anticolonialismo cultural, sobretudo na nova geração de intelectuais que, através de uma inversão, adequaram "[...] a razão como instrumento de dominação (onde) os parâmetros da racionalidade (foram) assimilados a componentes do poder (burguês) e, pois, desqualificados como vetores de libertação" (NETTO, 2011, p. 105).

É justamente no seio desse período histórico que podemos então identificar as bases para ascensão da chamada nova esquerda ou novos movimentos sociais no Brasil. Mas, diante das particularidades de nossa formação social, acreditamos que o Brasil convive com questões históricas e inconclusas, que evidenciam a importância e atualidade da luta antirracista, transcendendo esse marco histórico e o campo meramente culturalista.

Portanto, como pensar a realidade brasileira, considerando que em sua condição de capitalismo dependente, não alcançou o pleno - emprego e o Estado de Bem - Estar Social, mas sentiu os efeitos da crise capitalista, tendo sido impactado pela reestruturação produtiva do capital e ofensiva neoliberal? Como estabelecer reflexões sobre a influência do Maio de 68, mediante demandas históricas e tendências teórico-políticas tão diversas?

Temporalis, Brasília (DF), ano 20, n. 39, p. 146-162, jan./jun. 2020. | ISSN 2238-1856 
Como vimos, a luta antirracista é histórica na realidade brasileira e sempre buscou denunciar o racismo e o mito da democracia racial, afinal de contas, essa ideologia vêm produzindo estragos objetivos e subjetivos à população, em um país que usa em seu discurso oficial a inexistência do racismo, mas viola, mata, encarcera e abusa sexualmente de corpos negros em sua grande maioria.

A luta do movimento negro não nasceu de uma perspectiva revolucionária clássica, mas buscou reivindicar a existência humana, e, quando se articulou a esse projeto, experienciou encontros, desencontros e desgastes nessa relação, como na década de $30 \mathrm{com}$ o PCB ou na década de 80 com o PT.

Para além da influência e o intercâmbio com a experiencia internacional, como a luta pelos Direitos Civis nos EUA, a luta dos Panteras Negras, as lutas anticoloniais em África, a militância negra e a intelectualidade comprometida com a luta antirracista no Brasil inaugurou uma nova fase do movimento negro em fins dos anos 70, que buscou dialogar com uma perspectiva anticapitalista, articulada as organizaçõos partidárias de esquerda e os movimentos sociais em ascensão pela abertura democrática do país.

No bojo da ditadura civil-militar, os movimentos sociais e os partidos políticos de oposição se aliaram contra o capitalismo e a luta contra o racismo. A concepção do movimento negro, desde Jucelino Kubischek até o golpe civíl-militar de 1964, compreendia que a mobilidade social da população negra estava relacionada à sociedade de classes nos marcos do capitalismo, que a negava, e assim, deveria ser problematizada. Diante dessa interpretação foram surgindo agrupamentos como o Núcleo Negro Socialista ${ }^{4}$, uma organização embrionária que contribuiu na fundação do Movimento Negro Unificado (MNU), que vai inaugurar o diálogo entre raça e classe no final dos anos 70 (SILVA et. al, 2018).

A desvantagem social da população negra traria à tona a denúncia do movimento negro contra o racismo e a condição da classe trabalhadora negra. Conforme Santos (2005) nos mostra, a introdução da leitura marxista das categorias de raça e classe deram novo sentido histórico e teórico nessa luta, uma vez que a produção e reprodução do capitalismo não gera apenas mercadorias, mas, relações de dominação e opressão.

Foi diante dessa compreensão que pôde-se estabelecer a relação entre raça e classe no movimento negro, uma vez que o racismo passou a "[...] ser explicado como uma decorrência das relações sociorraciais desiguais e, como tal, se constitui em mais uma contradição da sociedade capitalista e autoritária a ser superado no processo de democratização da sociedade brasileira" (SANTOS, 2005, p. 22).

Os anos 70 e 80 se constituiu por um conjunto de expectativas diante da vida política brasileira, que impulsionou militantes de esquerda, inclusive dos movimentos sociais como o movimento negro, a se incorporarem nas organizações partidárias de esquerda. Dentre

\footnotetext{
${ }^{4}$ Fundado a partir do núcleo da Liga Operária na Convergência Socialista, o Núcleo Negro Socialista era uma organização trotskista, emergente em 1974, que atuava no movimento estudantil e nas lutas operárias. Já a Convergência Socialista, foi uma das correntes que fundou o Partido dos Trabalhadores na década de 1980 e anos depois o PSTU. Foi à partir desta articulação que houve uma maior incorporação de táticas e estratégias de luta contra o racismo nos partidos de esquerda.
}

Temporalis, Brasília (DF), ano 20, n. 39, p. 146-162, jan./jun. 2020. | ISSN 2238-1856 


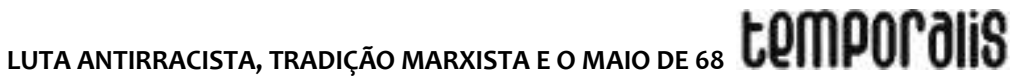

as expectativas, estava a possibilidade de disputa concreta dos espaços políticos institucionalizados, visando incidir sobre as pautas do movimento negro, que até então tinha uma representatividade quase inexistente. Dessa forma, ocorreu um ingresso significativo de lideranças negras, sobretudo no Partido dos Trabalhadores, que pode ser considerado o aglutinador de setores do movimento negro no período (LEITÃO, 2014).

Conforme relatos de assistentes sociais negras que impulsionaram o debate racial no Serviço Social no bojo da década de 80, como de Magali Almeida, o momento conjuntural em que o movimento negro vivenciava nos anos 80 se destacava pela seguinte direção:

\begin{abstract}
É muito importante mencionar que a discussão racial e a ação antirracista com vistas a combater o preconceito recebeu tanto a influência do movimento negro como de alguns partidos políticos 'de esquerda' na época. O MN teve uma estratégia muito importante, e uma delas defendia o seguinte pensamento: onde o negro está é necessário fazer a política antirracista. Ou seja, onde quer que estivéssemos, teríamos a tarefa de combater o racismo e as instituições a seu serviço. O MNU que reforçava essa linha. Parte dos negros estava em partidos diferentes [...]. Do ponto de vista partidário, avançamos muito. Primeiro, porque ousamos trazer este debate para as instituições de representação políticopartidárias. Nossa militância não era interna ao sindicato ou em partido - era no Movimento Social. Nossa tarefa era trazer os negros, perceber onde o negro estava. [...] É importante mencionar que o debate era direcionado ao negro. $O$ negro deveria militar para as bases (ALMEIDA, 2013, p. 232-233).
\end{abstract}

Mas, Soares (2012) irá demonstrar que no decorrer da construção da luta antirracista na esquerda brasileira, o diálogo e as pautas raciais passaram a ser estabelecidos de forma secundária e até demagógica, embora houvesse a defesa da população negra e a proposta de superação do racismo em algumas fileiras do pensamento marxista, e mesmo a incorporação da luta antirracista nos documentos e programas partidários.

Consequentemente, importantes quadros da militância negra foram rompendo com as organizações político-partidárias e seguindo um ativismo alternativo, que podemos até situar no campo dos novos movimentos sociais, mediante a nova conjuntura que se abria nos anos 90, de ofensiva neoliberal.

Muitas lideranças negras passaram a realizar seu ativismo político de maneira alternativa, pontual, pragmática e identitária seja através das redes sociais, do terceiro setor, de coletivos alternativos e independentes. Mas não deixaram a bandeira da luta antirracista.

Como buscamos apontar, as divergências foram motivadas sobretudo pelos encontros e desencontros entre a luta antirracista e a esquerda brasileira na história, que gerou um desgaste em meio à crise e as transformações societárias. A secundarização das pautas raciais, a falta de posições estratégicas e efetivas para a luta antirracista, o discurso genérico dos setores da esquerda sobre os trabalhadores e trabalhadoras e suas condições desiguais, a falta de atenção sobre a temática que ficou situada apenas no campo da militância negra foram alguns dos elementos tensionados nessa relação (SOARES, 2012).

\section{CONCLUSÃO}

Temporalis, Brasília (DF), ano 20, n. 39, p. 146-162, jan./jun. 2020. | ISSN 2238-1856 
Buscando apontar a necessidade de um balanço histórico entre a luta antirracista e a tradição marxista, a proposta desse artigo é dar visibilidade à temática, a partir de uma síntese do que foi a experiência histórica entre a luta antirracista e a tradição marxista, sobretudo em diálogo com as organizações partidárias de esquerda até os anos 80 . Contudo, foge de nosso alcance a possibilidade de uma análise detalhada de tais organizações.

Mediante erros e acertos, a luta antirracista na esquerda brasileira foi sobrevivendo em meio a complexidade e diversidade, que é o campo da interpretação marxista e de sua produção teórico-política. Mas, acreditamos que um importante balanço histórico possa motivar a apreensão do passado e as perspectivas que se abrem para o presente, sem desconsiderar o processo de conciliação de classes, a institucionalização dos movimentos sociais nas últimas décadas no Brasil o e ascenso da extrema-direita no mundo, que só tem fortalecido práticas discriminatórias, racistas e xenofóbicas.

Vários foram os tensionamentos nessa relação, e podemos citar experiências de importantes lideranças negras como Lélia Gonzales, Guerreiro Ramos, Clóvis Moura, Abdias Nascimento e assim por diante. A famosa frase de Sueli Carneiro entre esquerda e direita, continuo sendo preta, diz muito do que a esquerda precisa aprender sobre a luta antirracista e a realidade da população negra.

Assim, compreendemos que o significado da luta antirracista e anticapitalista é um grande desafio a ser consolidado, e ainda se encontra em construção.

\section{REFERÊNCIAS}

ALMEIDA, M. da S. Entrevista. Entrevistadores [JANOARIO, R. S.; ROCHA, R. F.; DIAS, S]. Libertas, Juiz de Fora: Universidade Federal de Juiz de Fora, v. 13, n.1, 2013.

ALMEIDA, S. L. O que é racismo estrutural? Belo Horizonte: Letramento, 2018.

BARBOSA, M. S. Pan - Africanismo e Teoria Social: uma herança crítica. Revista África, São Paulo: Universidade de São Paulo, v. 31-32, 2011/2012.

BIHR, A. Da grande noite a alternativa: o movimento operário europeu em crise. Tradução: BRANT, W. C. 2 ed. São Paulo: Boitempo, 2010.

BRAZ, M. Partido e Revolução: 1848-1989. São Paulo: Expressão Popular, 2011.

BUONICORE, A. C. Reflexões sobre o marxismo e a questão racial. Escola do PCdoB, 2005. Disponível em:

http://www.escolapcdob.org.br/file.php/1/materiais/pagina_inicial/Biblioteca/85_REFLEXO ES_SOBRE_O_MARXISMO_E_A_QUESTAO_RACIAL.pdf. Acesso em: 13 mar. 2018.

CHADAREVIAN, P. C. Raça, classe e revolução no partido comunista brasileiro (19221964). Política \& Sociedade, Florianópolis, v.11, n. 20, abr. 2012. 
CHADAREVIAN, P. C. Os precursores da interpretação marxista do problema racial.

Crítica Marxista, Campinas, n. 24, 2007.

DURIGUETTO, M. L. O olhar pós-moderno dos novos movimentos sociais. In: SEMINÁRIO LATINOAMERICANO DE ESCUELAS DE TRABAJO SOCIAL, 19., 2009, Guayaquil. Anais [...]. Guayaquil: Universidad Catolica Santiago de Guayaquil, 2009. Disponível em:

http://www.ts.ucr.ac.cr/binarios/congresos/reg/slets/slets-019-305.pdf . Acesso em: 10 set. 2019.

EVANGELISTA, J. E. Crise do marxismo e irracionalismo pós - moderno. 3. ed. São Paulo: Cortez, 2002.

HOBSBAWM, E. A era dos Extremos: o breve século XX: 1914 - 1919. São Paulo: Companhia das Letras, 1995.

HOBSBAWM, E. “O marxismo hoje: um balanço aberto”. In: HOBSBAWM, E. História do Marxismo. Vol XI. São Paulo: Paz e Terra, 1989.

JAMESON, F. Pós-modernismo: a lógica cultural do capitalismo tardio. São Paulo: Ática, 1996.

KONDER, L. O marxismo na batalha das ideias. Rio de Janeiro: Nova Fronteira, 1984.

LEITÃO, L. R. S. Entre o institucional e o contestatório: as lutas do movimento negro no Brasil (1970-1990). In: ENCONTRO ANUAL DA ANPOCS, 38., 2014, 2014. Disponível em: https://anpocs.com/index.php/encontros/papers/38-encontro-anual-da-anpocs/gt-1/gt141/8953-entre-o-institucional-e-o-contestatorio-as-lutas-do-movimento-negro-no-brasil1970-1990/file. Acesso em: 5 maio 2018.

LÖWY, M. O marxismo na América Latina: uma antologia de 1909 aos dias atuais. In: LÖWY, M. (org.). SCHILLING, C.; BORGES, L. C. (tradutores). 3. ed. ampl. São Paulo: Editora Fundação Perseu Abramo, 2012.

MANDEL, E. O capitalismo tardio. MATOS, C. E. S.; ANDRADE, R. C. A.; AZEVEDO, D. A. A. (tradução). São Paulo: Abril Cultural, 1982.

MOURA, C. Sociologia do Negro Brasileiro. São Paulo: Ática, 1988.

NASCIMENTO, E. L. Pan - Africanismo na América do Sul: emergência de uma rebelião negra. Petrópolis: Vozes, 1981.

NETTO, J. P. Ditadura e Serviço Social: uma análise do Serviço Social no Brasil pós-64. 16. ed. São Paulo: Cortez, 2011.

PEREIRA, A. A. "O mundo negro": relações raciais e a constituição do movimento negro contemporâneo no Brasil. Rio de Janeiro: Pallas: FAPERJ, 2013.

SANTOS, G. A luta contra o racismo na esquerda brasileira. In: IANNI, O. [et.al.]. O negro e o socialismo. São Paulo: Fundação Perseu Abramo, 2005.

Temporalis, Brasília (DF), ano 20, n. 39, p. 146-162, jan./jun. 2020. | ISSN 2238-1856 
SILVA, S. R. V.; VALDO, J. P. S.; COSTA, N. C.; SILVA, V. A.; ALFREDO, D. S. Raça, Classe e Serviço Social: contribuições ao debate. In: ENCONTRO NACIONAL DE PESQUISADORES EM SERVIÇO SOCIAL, 16., 2018, Vitória. Anais [...]. Vitória: Universidade Federal do Espírito Santo, 2018. Disponível em:

file://C:/Users/Sandra/Downloads/22766-Texto\%20do\%20artigo-65646-1-10-20181211.pdf. Acesso em: 5 maio 2019.

SOARES, C. G. Raça, classe e ação afirmativa na trajetória política de militantes negros de esquerda. Política e Sociedade, Florianópolis, v.11, n. 22, p. 41- 74, 2012.

\section{Sandra Regina Vaz Silva}

Professora da Escola de Serviço Social da Universidade Federal Fluminense. Doutoranda do Programa de Pós Graduação em Serviço Social da UFRJ. Coordenadora do Grupo de Estudos e Pesquisa sobre Questão Racial e Serviço Social da ESS/UFF. 